(6)

OPEN ACCESS

\title{
Boerhaave's syndrome in an ultra-distance runner
}

\author{
Andrew Pasternak, ${ }^{\oplus 1,2}$ JoAnn Ellero, ${ }^{3}$ Stephen Maxwell, ${ }^{4}$ Victoria Cheung ${ }^{5}$
}

${ }^{1}$ Silver Sage Center for Family Medicine, Reno, Nevada, USA ${ }^{2}$ Department of Family Medicine, University of Nevada Reno,

Reno, Nevada, USA

${ }^{3}$ Associated Anesthesiologists of Reno, Reno, Nevada, USA

${ }^{4}$ Sutter Medical Center Sacramento, Roseville, California, USA

${ }^{5}$ Saint Joseph's Health Centre, Toronto, Ontario, Canada

\section{Correspondence to} Dr Andrew Pasternak, avpiv711@sbcglobal.net

Accepted 20 June 2019

\section{SUMMARY}

A runner competing in a 100 mile trail race presented with severe lower chest pain and right upper abdominal pain. His pain started immediately after he took an over the counter non steroidal anti-inflammatory pill a few hundred metres after leaving the aid station. When he took the pill, he immediately had to vomit and spit out the pill. On arriving back at the aid station, he was noted to have severe left-sided chest pain that worsened with reclining. He also had profound dyspnoea. Initial vital signs were unremarkable. The runner was immediately transported to an emergency room and eventually found to have an oesophageal rupture. After surgical intervention and a lengthy recovery, the runner is back to participating in sport.

\section{BACKGROUND}

The most common concern for athletes with chest pain is typically to evaluate them for cardiac causes. Other aetiologies for chest pain, however, need to be considered, especially if the patient has an atypical presentation or if the athlete is at low risk of cardiac events. Boerhaave's syndrome (effort induced oesophageal rupture) is a rare cause of chest pain and is typically seen in older patients.

\section{CASE PRESENTATION}

Western States 100 is an ultramarathon from Squaw Valley, California to Auburn, California. A 37-year-old runner was competing in his first 100 mile race. He had not had any vomiting up to that point of the race. Soon after leaving, his pacer returned to the aid station requesting medical help: his runner was complaining of being unable to breathe and severe right-sided chest pain and right upper quadrant abdominal pain.

On initial examination on the trail, he was holding his side and complaining of severe left-sided chest pain and dyspnoea. His pain started after he

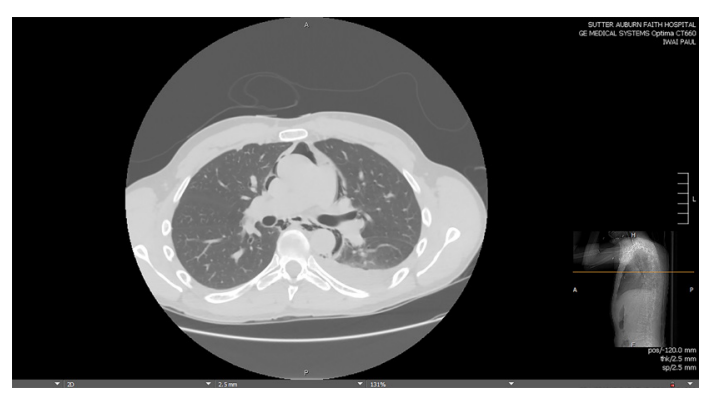

Figure $1 \mathrm{CT}$ chest showing pneumomediastinum and left pleural effusion. took an over the counter non-steroidal anti-inflammatory pill. He never swallowed the pill because as soon as he took the pill, he immediately felt like he needed to vomit. On vomiting, he had severe pain to the point where the runner thought perhaps he had broken a rib.

Vitals were normal, including a pulse oximetry reading of 95\%. Lying down made his chest pain significantly worse, especially on the left side. Emergency services were activated and he was transported to a local emergency room. On arrival in the emergency room, notable vitals included a respiratory rate of 22 breaths/min, pulse rate of 77 bpm and an oxygen saturation of $93 \%$.

\section{INVESTIGATIONS}

Initial ECG was unremarkable. Laboratory evaluation showed an elevated white count of $17.8 \mathrm{~K} /$ $\mu \mathrm{L}$ with a left shift. Serum blood urea nitrogen was elevated at 50 with a creatinine of 2.3. Creatine phosphokinase was elevated at $5349 \mathrm{U} / \mathrm{L}$ and his brain natriuretic peptide level was also mildly elevated at $614 \mathrm{pg} / \mathrm{dL}$. Troponin I was slightly elevated at $0.09 \mathrm{ng} / \mathrm{mL}$ and d-dimer was elevated at $598 \mathrm{ng} / \mathrm{mL}$. A chest x-ray showed a large patchy infiltrate in the left lung base with no evident pleural effusion, pneumothorax or pulmonary oedema, along with pneumomediastinum with extensive dissection of soft tissue gas. Contrast CT was contraindicated because of his elevated renal function. A non-contrast CT was performed which showed extensive dissection of the pneumomediastinum into his bilateral upper hemithorax and neck (figure 1). Small bilateral pleural effusions were also noted along with a consolidating infiltrate in the left lower lobe.

He was admitted to hospital. A d-dimer was repeated which was normal. About 12 hours after initially presenting, a single contrast oesophagram revealed a left lateral distal oesophageal perforation with extravasation of gastrograffin into the mediastinum (figure 2).

\section{DIFFERENTIAL DIAGNOSIS}

Differential diagnoses included acute myocardial infarction, rib fracture, pneumothorax, pulmonary embolism, bowel perforation with free air in the abdomen, ruptured aortic aneurysm and diaphragmatic rupture.

\section{TREATMENT}

The runner was transferred to a hospital for consultation with a thoracic surgeon for Boerhaave's syndrome. He underwent a bronchoscopy, left 


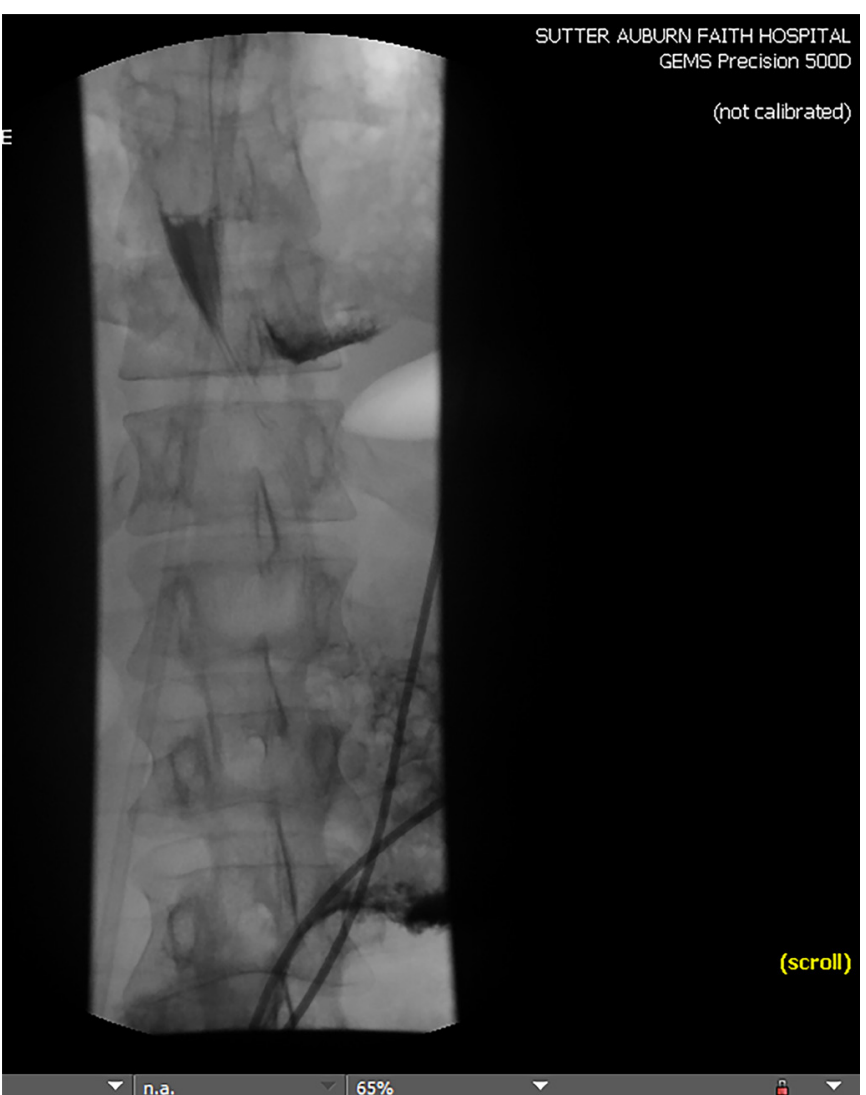

Figure 2 Upper gastrointestinal tract showing contrast outside the lumen of his oesophagus and along the contour of the diaphragm on the left side.

thoracotomy with total pulmonary decortication, primary repair of the distal oesophageal perforation, mediastinal debridement, intercostal muscle flap pedicle based on intercostal artery, open surgical gastrostomy tube placement and surgical jejunostomy tube placement. Four days postoperatively, anterior chest tubes were removed. Posterior chest tubes were removed after 6 days. Unfortunately he developed a recurrent effusion and chest tubes were reinserted by interventional radiology. A repeat oesophagram showed a persistent leak. At that point there was discussion of oesophageal stent placement versus conservative treatment. The runner elected for conservative management.

\section{OUTCOME AND FOLLOW-UP}

After 15 days in hospital, the patient was transferred by medical transport back to his home town for further hospitalisation where he spent another 10 days in hospital. He had a persistent controlled leak, and an enlarging pleural collection requiring drainage with placement of an additional chest tube by interventional radiology. Conservative management continued with nutrition via a J-tube and intravenous antibiotics. Over the next 2 weeks, the leak healed and he was discharged home. Upper endoscopy 1 month later showed complete healing of his oesophageal perforation. Three months later, he was back to eating a full diet and back to running on the trails.

\section{DISCUSSION}

Boerhaave's syndrome, or spontaneous oesophageal rupture, is an uncommon condition. While up to $96 \%$ of ultrarunners will have some gastrointestinal distress during a race, we have not seen this complication described in the literature. ${ }^{1}$ A study in

\section{Patient's perspective}

The oesophageal rupture that I experienced during the Western States endurance run was a scary situation for me. After I vomited, I felt an intense pain in my abdominal area and breathing was very difficult. I thought perhaps I was 'winded' temporarily, but my breathing did not improve. When I was in the first ambulance, the paramedic treated me as if I was having a heart attack. I did not realise the seriousness of my situation until I saw the look of concern in the radiologist's eyes after the contrast $x$-ray revealed the rupture. For several days after my surgery, I felt very dehydrated and was desperately craving a glass of water. But I finally felt hydrated again 5 days post surgery and began the road to recovery. I ended up spending a total of 41 days in three hospitals and over 30 days being fed through a J-tube. I had to learn to breathe again, walk again, and after 70 days I was able to start running again. The whole experience gave me a new perspective on life and the importance of health, and I have learnt to appreciate the little things in life.

\section{Learning points}

Boerhaave's syndrome, while uncommon, can occur in athletes.

- Nausea and vomiting are commonly seen in ultra endurance races. While they limit performance, they are benign; Boerhaave's is a more serious consequence.

- Gastrointestinal aetiology of chest pain should be considered in athletes with chest pain.

Iceland demonstrated an incidence of 3.1/1 000000 per year of overall oesophageal rupture and of that, only $24 \%$ of cases were categorised as spontaneous ruptures. ${ }^{2}$ First described by the Dutch physician Hermann Boerhaave in 1724, the condition was uniformly fatal until the first reported successful surgery in 1947. Spontaneous oesophageal ruptures occur more frequently in men than women and typically affect men aged 40-60 years who overindulge in alcohol and food. ${ }^{3}$ Only $5 \%$ of patients with Boerhaave's syndrome are considered to be healthy with no underlying aetiology. ${ }^{4}$

Patients with Boerhaave's syndrome usually present with severe chest pain after an episode of violent vomiting. Ruptures typically take place on the left side in the distal third of the oesophagus. While pain is often the primary symptom, other symptoms can include dyspnoea, voice changes, dysphagia and subcutaneous emphysema. A chest $\mathrm{x}$-ray is helpful in making the diagnosis since patients with Boerhaave's syndrome will have an abnormal x-ray $81-90 \%$ of the time, although within the first 6 hours of the perforation, $10-33 \%$ of patients will have normal chest $\mathrm{x}$-ray findings. ${ }^{3}$ To confirm the diagnosis, gastrointestinal tract contrast CT has a better sensitivity than an upper gastrointestinal tract contrast study. ${ }^{5}$ Oesophageal endoscopy also has a near $100 \%$ sensitivity but insufflation may make the tear larger.

Mortality rates can be as high as $80 \%$ although improvements in recognition and treatment now show rates of $2-20 \% .^{6}$ Prompt recognition is important as the mortality rate doubles when treatment is delayed after 24 hours. ${ }^{7}$ Initial treatment includes fluid resuscitation, intravenous antibiotics and antifungals, and prompt referral to an appropriate treatment centre. Historically, surgery has been the definitive 
treatment, although newer options using endoscopic stenting, endoscopic glueing, endoscopic clipping, tube thoracostomy and/or feeding gastrostomy tubes have shown promise. ${ }^{589} \mathrm{~A}$ severity scoring system has been used to help stratify treatment options. $^{10}$

Contributors AP: initial care of the patient. Involved in writing the first draft of the manuscript, literature review and revisions. Obtained consent from the patient and involved the patient in reviewing the case. JAE: initial care of the patient. Involved in writing the first draft of the manuscript, literature review and revisions. SM: surgeon who performed the initial operation. Reviewed/edited the manuscript and provided details on initial hospital management. Provided images for the manuscript. VC: surgeon who provided subsequent care. Reviewed/edited the manuscript and provided details on follow-up care.

Funding The authors have not declared a specific grant for this research from any funding agency in the public, commercial or not-for-profit sectors.

Competing interests None declared.

Patient consent for publication Obtained.

Provenance and peer review Not commissioned; externally peer reviewed.

Open access This is an open access article distributed in accordance with the Creative Commons Attribution Non Commercial (CC BY-NC 4.0) license, which permits others to distribute, remix, adapt, build upon this work non-commercially, and license their derivative works on different terms, provided the original work is properly cited and the use is non-commercial. See: http://creativecommons.org/ licenses/by-nc/4.0/

\section{REFERENCES}

1 Stuempfle KJ, Hoffman MD. Gastrointestinal distress is common during a $161-\mathrm{km}$ ultramarathon. J Sports Sci 2015;0414:1-8.

2 Vidarsdottir $\mathrm{H}$, Blondal $\mathrm{S}$, Alfredsson $\mathrm{H}$, et al. Oesophageal perforations in Iceland: a whole population study on incidence, aetiology and surgical outcome. Thorac Cardiovasc Surg 2010;58:476-80.

3 Rokicki M, Rokicki W, Rydel M. Boerhaave's syndrome- over 290 years of surgical experiences, epidemiology, pathophysiology, dlagnosis. Pol Przedglad Chiruggiczny 2016;88:359-64.

4 Brauer RB, Liebermann-Meffert D, Stein HJ, et al. Boerhaave's syndrome: analysis of the literature and report of 18 new cases. Dis Esophagus 1997;10:64-8.

5 Chirica M, Champault A, Dray X, et al. Esophageal perforations. J Visc Surg 2010;147:e117-28.

6 Carrott PW, Low DE. Advances in the management of esophageal perforation. Thorac Surg Clin 2011;21:541-55.

7 Brinster CJ, Singhal S, Lee L, et al. Evolving options in the management of esophageal perforation. Ann Thorac Surg 2004;77:1475-83.

8 Kuppusamy MK, Hubka M, Felisky CD, et al. Evolving management strategies in esophageal perforation: surgeons using nonoperative techniques to improve outcomes. J Am Coll Surg 2011;213:164-71.

9 Sepesi B, Raymond DP, Peters JH, et al. Endoscopic and medical management strategies. Curr Opin Gastroenterol 2010;26:379-83.

10 Abbas G, Schuchert MJ, Pettiford BL, et al. Contemporaneous management of esophageal perforation. Surgery 2009;146:749-56.

Copyright 2019 BMJ Publishing Group. All rights reserved. For permission to reuse any of this content visit

https://www.bmj.com/company/products-services/rights-and-licensing/permissions/

BMJ Case Report Fellows may re-use this article for personal use and teaching without any further permission.

Become a Fellow of BMJ Case Reports today and you can:

- Submit as many cases as you like

- Enjoy fast sympathetic peer review and rapid publication of accepted articles

- Access all the published articles

Re-use any of the published material for personal use and teaching without further permission

Customer Service

If you have any further queries about your subscription, please contact our customer services team on +44 (0) 2071111105 or via email at support@bmj.com.

Visit casereports.bmj.com for more articles like this and to become a Fellow 